\title{
Plant compounds insecticide activity against Coleoptera pests of stored products
}

\author{
Márcio Dionizio Moreira(1), Marcelo Coutinho Picanço(1), Luiz Cláudio de Almeida Barbosa(2), \\ Raul Narciso Carvalho Guedes ${ }^{(1)}$, Mateus Ribeiro de Campos(1), Gerson Adriano Silva(1) and Júlio Cláudio Martins ${ }^{(1)}$ \\ (1)Universidade Federal de Viçosa (UFV), Dep. de Biologia Animal, Av. P.H. Rolfs, s/no, CEP 36570-000 Viçosa, MG, Brazil. \\ E-mail: marcio.dionizio@gmail.com, picanco@ufv.br, guedes@ufv.br, mateusc3@yahoo.com.br, agronomiasilva@yahoo.com.br, \\ julioufv@yahoo.com.br (2)UFV, Dep. de Química. E-mail: Icab@ufv.br
}

\begin{abstract}
The objective of this work was to screen plants with insecticide activity, in order to isolate, identify and assess the bioactivity of insecticide compounds present in these plants, against Coleoptera pests of stored products: Oryzaephilus surinamensis L. (Silvanidae), Rhyzopertha dominica F. (Bostrichidae) and Sitophilus zeamais Mots. (Curculionidae). The plant species used were: basil (Ocimum selloi Benth.), rue (Ruta graveolens L.), lion's ear (Leonotis nepetifolia (L.) R.Br.), jimson weed (Datura stramonium L.), baleeira herb (Cordia verbenacea $\mathrm{L}$.), mint (Mentha piperita $\mathrm{L}$.), wild balsam apple (Mormodica charantia L.), and billy goat weed or mentrasto (Ageratum conyzoides L.). The insecticide activity of hexane and ethanol extracts from those plants on R. dominica was evaluated. Among them, only hexane extract of A. conyzoides showed insecticide activity; the hexane extract of this species was successively fractionated by silica gel column chromatography, for isolation and purification of the active compounds. Compounds 5,6,7,8,3',4', $5^{\prime}$-heptamethoxyflavone; 5,6,7,8,3'pentamethoxy-4',5'-methilenedioxyflavone and coumarin were identified. However, only coumarin showed insecticide activity against three insect pests $\left(\mathrm{LD}_{50}\right.$ from 2.72 to $39.71 \mathrm{mg} \mathrm{g}^{-1}$ a.i.). The increasing order of insects susceptibility to coumarin was $R$. dominica, $S$. zeamais and $O$. surinamensis.
\end{abstract}

Index terms: natural insecticide, pest management, alternative control, secondary metabolites.

\section{Compostos de plantas com atividade inseticida a coleópteros-praga de produtos armazenados}

\begin{abstract}
Resumo - O objetivo deste trabalho foi selecionar plantas com atividade inseticida, para isolar, identificar e avaliar a bioatividade de compostos inseticidas presentes nessas plantas, contra as seguintes pragas de produtos armazenados da ordem Coleoptera: Sitophilus zeamais Mots. (Curculionidae), Rhyzopertha dominica F. (Bostrichidae) e Oryzaephilus surinamensis L. (Silvanidae). As espécies de plantas usadas foram: anis (Ocimum selloi Benth), arruda (Ruta graveolens L.), cordão-de-frade (Leonotis nepetifolia L.), datura (Datura stramonium L.), erva baleeira (Cordia verbenacea L.), hortelã (Mentha piperita L.), melão-de-são-caetano (Mormodica charantia L.) e mentrasto (Ageratum conyzoides L.). Avaliou-se a toxicidade dos extratos hexânico e etanólico dessas plantas sobre $R$. dominica. Somente o extrato hexânico de A. conyzoides apresentou atividade inseticida. $\mathrm{O}$ extrato hexânico desta planta foi fracionado, sucessivamente, por cromatografia de coluna de sílica gel, para isolamento e purificação dos compostos ativos. Os compostos 5,6,7,8,3',4',5'-heptametoxiflavona; 5,6,7,8,3'-pentametoxi-4',5'-metilenodioxiflavona e cumarina foram identificados. Entretanto, somente a cumarina apresentou atividade inseticida às três espécies de insetos ( $\mathrm{DL}_{50}$ de 2,72 a $39,71 \mathrm{mg} \mathrm{g}^{-1}$ de i.a.). A ordem crescente de suscetibilidade à cumarina foi $R$. dominica, S. zeamais e $O$. surinamensis.
\end{abstract}

Termos para indexação: inseticida natural, manejo de pragas, controle alternativo, metabolito secundário.

\section{Introduction}

Stored insect pests are a problem throughout the world, because they reduce the quantity and quality of grain. Their damage to stored grains and grain products may amount to $5-10 \%$ in the temperate zone and $20-30 \%$ in the tropical zone (Nakakita, 1998). Such damage may reach up to $40 \%$, in countries where modern storage technologies have not been introduced (Shaaya et al., 1997).

The use of chemical agents to prevent or control insect infestations has been the main method of grain protection, since it is the simplest and most cost-effective means of dealing with stored product pests (Hidalgo et al., 1998). 
However, insecticides have serious drawbacks such as pest resurgence and resistance, lethal effects on nontarget organisms, the risk of users contamination, food residues, and environmental pollution (Tapondjou et al., 2002). In addition, the precautions necessary to work with traditional chemical insecticides (Fields et al., 2001), and the poor storage facilities of traditional farmers in developing countries, which are unsuitable for effective conventional chemical control (Tapondjou et al., 2002), emphasize the necessity of new and effective methods for insect pest control of stored products.

Thus, there is an urgent need to develop safe alternatives to conventional insecticides and fumigants for the protection of grain products against insect infestations. There are increasing efforts to understand indigenous pest control strategies, with a view to reviving and modernizing their use (Shaaya et al., 1997; Belmain et al., 2001). Higher plants are a rich source of novel insecticides (Dev \& Koul, 1997). Plant materials with insecticidal properties have been used traditionally for generations throughout the world (Belmain et al., 2001). Botanical insecticides compared to synthetic ones may be safer for the environment, are, generally, less expensive, easily processed and used by farmers and small industries (Belmain et al., 2001). Since these insecticides are often active against a limited number of species, are often biodegradable to nontoxic products, and are potentially suitable for use in integrated pest management, they could lead to the development of new classes of safer insect control agents (Kim et al., 2003).

The best known and successful example of insecticide discovery from plant is the natural pyrethrin, found in Chrysanthemum sp., which leads to development of the most used class of synthetic insecticides: pyrethroids (Zito et al., 1983). Neem, Azadirachta indica from Meliaceae family, is the most important botanical insecticide presently in use through the world (Brunherotto \& Vendramim, 2001). However, many other plant species, especially from tropical regions, have the potential to be used as botanical insecticide or as font of bioactive compounds (Saxena et al., 1992; Quignard et al., 2003; Shaalan et al., 2005).

The objective of this work was to screen plants with insecticide activity, in order to isolate, identify and assess the bioactivity of insecticide compounds, present in the bioactive plant, against Coleoptera pest of stored products.

\section{Material and Methods}

Toxicity bioassays were carried out with adults of $S$. zeamais, $R$. dominica and $O$. surinamensis. $S$. zeamais and $R$. dominica were reared on insecticidefree whole corn, and $O$. surinamensis was reared on insecticide-free flour corn. They were incubated at $25 \pm 0.5^{\circ} \mathrm{C}, 75 \pm 5 \%$ r.h. and 12 -hour photophase.

In the first bioassay, bioactive hexane and ethanol extracts of eight plant species with insecticide activity were evaluated against $R$. dominica. The plant species used were: basil (Ocimum selloi B.), rue (Ruta graveolens L.), lion's ear (Leonotis nepetifolia L.), jimson weed (Datura stramonium L.), baleeira herb (Cordia verbenaceae L.), mint (Mentha piperita L.), wild balsam apple (Mormodica charantia L.), and billy goat weed (A. conyzoides L.). Those plants were selected based on popular knowledge of their insecticidal properties (Guerra, 1985).

Samples of $500 \mathrm{~g}$ of each plant species were collected in the Campus of Universidade Federal de Viçosa, Minas Gerais State, Brazil. Each sample was placed in $1 \mathrm{~L}$ Erlenmeyer flasks for hexane extraction. The solvent was removed by filtration after 48 hours. Ethanol extraction was carried out by graining the samples with solvent and waiting for 48 hours. The hexane and ethanol extracts were concentrated under low pressure and reduced temperature $\left(<50^{\circ} \mathrm{C}\right)$, and were diluted with the respective solvent at the concentration of $20 \mathrm{mg} \mathrm{mL}^{-1}$.

The filter paper ( $9 \mathrm{~cm}$ of diameter) received $1 \mathrm{~mL}$ of these extracts, and was placed on Petri dish $(9 \mathrm{~cm}$ of diameter). The control was treated with pure solvents. After the solvent evaporation, 10 nonsexed adult of $R$. dominica were placed in each Petri dish, maintained under $25 \pm 0.5^{\circ} \mathrm{C}, 75 \pm 5 \%$ r.h. and 12 -hour photophase. The experimental design was completely randomized, with three replicates. Insect mortality was evaluated after 4 and 24 hours of exposure to impregnated filter paper. Mortality data were subjected to variance analysis, and means were compared by Scott-Knott test, at $5 \%$ of probability.

For the second bioassay, $5.31 \mathrm{~kg}$ of A. conyzoides leaves were used to extraction of pure compounds with hexane (extract selected in the first bioassay). The solvent was changed into intervals of two days, during 45 days. The extraction was concluded when the solvent stayed colorless. The extract obtained was concentrated under low pressure and reduced temperature $\left(<50^{\circ} \mathrm{C}\right)$. Some compounds were isolated by fractioning the extract 
with silica gel 60 (70-230 Mesh) column chromatography. Hexane with increasing portions of diethyl ether and methanol was used as eluent. Thin layer chromatography (TLC, Silica gel 60 F254 $0.25 \mathrm{~mm}$ ) was used to identify fractions containing similar compounds. The solvent was removed under low pressure and reduced temperature $\left(<50^{\circ} \mathrm{C}\right)$. The melting points (m.p.) were determined in apparatus Microquímica MQAPF-301. Proton Nuclear Magnetic Resonance $\left({ }^{1} \mathrm{H}\right.$ NMR) Spectroscopy (Bruker WM 400 or Varian Mercury $300, \mathrm{CDCl}_{3}$ ) was used to identify the isolated compounds.

The compounds were topically applied at doses of $10 \mathrm{mg} \mathrm{g}^{-1}$ of body mass to $R$. dominica, $S$. zeamais, and $O$. surinamensis. The experimental design was completely randomized, with three replicates. Each replicate was a Petri dish $(9 \mathrm{~cm}$ diameter $)$ with 10 nonsexed adult insects, maintained under $25 \pm 0.5^{\circ} \mathrm{C}$, $75 \pm 5 \%$ r.h. and 12 -hour photophase. The control was treated with the same amount of the solvent acetone. Insect mortality was assessed at 6, 12, 24 and 48 hours after topical exposure. Mortality data were subjected to variance analysis, and means were compared by ScottKnott test, at $5 \%$ of probability.

In the third bioassay, the adult insects of $S$. zeamais, $R$. dominica, and $O$. surinamensis (10 per replicate) were submitted to increasing doses of coumarin by topical application. The experimental design was completely randomized, with four replicates. Each replicate was a Petri dish (9 $\mathrm{cm}$ diameter) with 10 nonsexed adult insects, maintained under $25 \pm 0.5^{\circ} \mathrm{C}$, $75 \pm 5 \%$ r.h., and 12-hour photophase. Insect mortality was assessed at 6,12 and, 24 hours after the topical exposure. The data were corrected for control mortality (Abbott, 1925), and probit analysis was carried out for toxicity estimation (Tallarida, 2000).

\section{Results and Discussion}

Among the eight plants screened, only the hexane crude extract of $A$. conyzoides showed insecticide activity, with 76 and $88.67 \%$ mortality of $R$. dominica, at 4 and 24 hours after the exposure, respectively (Table 1). In agreement with this work, Saxena et al. (1992) observed some acute toxic effect of polar extracts, obtained with petroleum ether and acetone of A. conyzoides against Culex quinquefasciatus Say (Diptera: Culicidae). Bouda et al. (2001) also observed insecticide activity of essential oils of A. conyzoides against Sitophilus zeamais at concentrations of 0.013, $0.025,0.05,0.10 \%$.

The extraction of $5.31 \mathrm{~kg}$ of A. conyzoides leaves, with hexane, produced $86.13 \mathrm{~g}$ of crude extract. A crystallized portion $(8.76 \mathrm{~g}$ ) was separated from the crude extract by filtration. Hexane, hexane:diethyl ether (100:0.5 and 50:50), pure diethyl ether, and pure methanol solvent were used as eluent. A portion of $77.37 \mathrm{~g}$ of the crude extract was partitioned by open column chromatography into $1 \mathrm{~L}$. The fractions with similar compounds were CF1, CF2, CF3, CF4, CF5, CF6, CF7, $\mathrm{CF} 8$ and $\mathrm{CF} 9$. The compound 1 was isolated from $\mathrm{CF} 7$ with solvent mixture hexane:diethyl ether (10:4) as mobile phase. The compounds 2 and 3 were isolated from the crystallized portion, using solvent mixture hexane:diethyl ether (10:1), as eluent.

Compound 1 ( $4.2 \mathrm{~g})$ was isolated, as a yellow solid, with melting point (m.p.) from 115.3 to $116.9^{\circ} \mathrm{C}$. This compound was identified by its ${ }^{1} \mathrm{H}$ NMR spectra (Figure $1 \mathrm{~A}$ ) and confirmed as the flavonoid 5,6,7,8,3', 4', 5' -heptamethoxyflavone. The ${ }^{1} \mathrm{H}$ NMR spectra showed singlets at $\delta 3.92,3.94,4.01,4.10,6.63$

Table 1. Mortality (\%) of Rhyzopertha dominica, at 4 and 24 hours after exposure to hexane and ethanol extracts of eight plant species $^{(1)}$.

\begin{tabular}{lrrr}
\hline Plant species & \multicolumn{2}{c}{ Hexane extract } & Ethanol extract \\
\cline { 2 - 3 } & \multicolumn{1}{c}{$4 \mathrm{~h}$} & $24 \mathrm{~h}$ & $4 \mathrm{~h}$ \\
Control & $0.00 \pm 0.00 \mathrm{aB}$ & $0.00 \pm 0.00 \mathrm{aB}$ & $0.00 \pm 0.00 \mathrm{aB}$ \\
Ageratum conyzoides & $76.00 \pm 2.35 \mathrm{aA}$ & $88.67 \pm 1.67 \mathrm{aA}$ & $0.00 \pm 0.00 \mathrm{aB}$ \\
Ruta graveolens & $0.00 \pm 0.00 \mathrm{aB}$ & $0.00 \pm 0.00 \mathrm{aB}$ & $0.00 \pm 0.00 \mathrm{aB}$ \\
Leonotis nepetifolia & $0.00 \pm 0.00 \mathrm{aB}$ & $0.00 \pm 0.00 \mathrm{aB}$ & $0.00 \pm 0.00 \mathrm{aB}$ \\
Cordia verbenacea & $1.63 \pm 0.00 \mathrm{aB}$ & $0.00 \pm 0.00 \mathrm{aB}$ & $0.00 \pm 0.00 \mathrm{aB}$ \\
Datura stramonium & $0.00 \pm 0.00 \mathrm{aB}$ & $0.00 \pm 0.00 \mathrm{aB}$ & $0.00 \pm 0.00 \mathrm{aB}$ \\
Mormodica charantia & $0.00 \pm 0.00 \mathrm{aB}$ & $0.00 \pm 0.00 \mathrm{aB}$ & $0.00 \pm 0.00 \mathrm{aB}$ \\
Ocimum selloi & $0.00 \pm 0.00 \mathrm{aB}$ & $0.00 \pm 0.00 \mathrm{aB}$ & $0.00 \pm 0.00 \mathrm{aB}$ \\
Mentha piperita & $0.00 \pm 0.00 \mathrm{aB}$ & $0.00 \pm 0.00 \mathrm{aB}$ & $0.00 \pm 0.00 \mathrm{aB}$ \\
\hline
\end{tabular}

(1) Means followed by the equal small case letters in the line or equal capital letters in the column are not significantly different by the Scott-Knott test, at $5 \%$ probability. 
and 7.15. Compound 2(5.28 g), isolated as a white solid, showed m.p. from 66.7 to $68.9^{\circ} \mathrm{C}$. The data obtained of ${ }^{1} \mathrm{H}$ NMR, signs at $\delta 5.59$ (doublet, $\mathrm{J}=9.6$ ), 6.49 (multiplet), 6.68 (multiplet) and 6.90 (doublet, $\mathrm{J}=9.6$ ), allowed to confirm the structure of this compound as coumarin (Figure $1 \mathrm{~B}$ ). Compound 3 $(0.46 \mathrm{~g})$ showed m.p. from 185 to $188.9^{\circ} \mathrm{C}$. The ${ }^{1} \mathrm{H}$ NMR spectra for the compound 3 showed singlets at 3.91, 3.92, 3.95, 3.98, 4.07, 6.05, 6.53 and doublets at 7.06 and $7.11(\mathrm{~J}=1.7)$. Compound 3 was recognized as 5,6,7,8,3'-pentamethoxy-4',5'-methylenedioxyflavone (Figure 1 C).
Absorptions corresponding to 24 hydrogens were observed from ${ }^{1} \mathrm{H}$ NMR spectrum, for 5,6,7,8,3', 4', 5'heptamethoxyflavone. The NMR signs at $\delta 3.92$ and $\delta 4.10$ were integrated for 21 hydrogens, and attributed to seven metoxyl groups. The singlet at $\delta 7.15$ resulted from hydrogens $\mathrm{H}-2$ ' and H-6', because of aromatic ring symmetry. The singlet at $\delta 6.63$ corresponds to H-3 (Figure $1 \mathrm{~A}$ ). The data of compound 1 were consistent with those reported by Le-Van \& Pham (1979), who isolated the same compound from Eupatorium coelestinum. The ${ }^{1} \mathrm{H}$ NMR spectrum for compound 2 was a characteristic of coumarin. The doublets at $\delta 5.59$



Figure 1. ' $\mathrm{H}$ NMR spectra (300 MHz, CDCl3) of the compound 5,6,7,8,3',4',5'-heptamethoxyflavone (A); coumarin (B); 5,6,7,8,3'pentamethoxy-4',5'-methylenedioxyflavone (C). 
and $\delta 6.90$ correspond, respectively, to $\mathrm{H}-3$ and $\mathrm{H}-4$ $(\mathrm{J} 1=9.6)$. $\mathrm{H}-6$ and $\mathrm{H}-8$, as well as $\mathrm{H}-5$ and $\mathrm{H}-7$, showed peaks, respectively, at $\delta 6.68$ and $\delta 6.49$ (Figure $1 \mathrm{~B}$ ). The spectrum of ${ }^{1} \mathrm{H}$ NMR for 5,6,7,8,3'-pentamethoxy-4',5'methylenedioxyflavone was similar to that of compound 1 . However, it was observed from ${ }^{1} \mathrm{H}$ NMR spectrum absorptions corresponding to 20 hydrogens. Peaks between $\delta 3.95$ and $\delta 4.11$ were attributed to 15 hydrogens of five metoxyl groups. The singlet of hydrogens linked at carbons 3 and 16 (methylenodioxy) were observed at $\delta 6.57$ and $\delta 6.09$, respectively. The doublets at $\delta 7.11$ and $\delta 7.06(\mathrm{~J}=1.7 \mathrm{~Hz})$ correspond to hydrogens linked to carbons 2 ' and 6' (Figure $1 \mathrm{C}$ ). The ${ }^{1} \mathrm{H}$ NMR spectra were consistent with Quijano et al. (1980).

The second bioassay with the three identified compounds showed significant insecticide activity for coumarin against three insect pests (Table 2). The compound 5,6,7,8,3',4',5'-heptamethoxyflavone showed toxicity only to $R$. dominica 48 hours after the application, and 5,6,7,8,3'-pentamethoxy-4', 5' methylenedioxyflavone showed no toxicity to the three insects species (Table 2). Thus, dose-mortality curves, in the third bioassay, for the compounds $5,6,7,8,3^{\prime}, 4^{\prime}, 5^{\prime}$ heptamethoxyflavone and 5,6,7,8,3'-pentamethoxy-4',5'methylenedioxyflavone for $S$. zeamais, $R$. dominica, and $O$. surinamensis were not obtained, due to lack of activity against these species.

Other studies reported activity of this group of compounds to other insect species. This group of compounds has been reported as antifeedant and growth inhibitors to insect, probably for their interference in hormone mechanisms (Onyilagha et al., 2004). The flavonoids possess a catecholic B-ring that seems to be responsible for the toxicant activity to insects (Onyilagha et al., 2004), and this activity vary in agreement with the chemical structure of these compounds (Larsson et al., 1992). Thus, a great variation is expected in the activity of these compounds, because they represent a group with great structural diversity.

Coumarin dose-mortality curves related to $S$. zeamais, $R$. dominica, and $O$. surinamensis were obtained (Table 3). The coumarin dose-mortality curve for O. surinamensis showed the steppest slopes for all evaluation times. In general, the slopes obtained for $R$. dominica were smaller. The toxicity of coumarin in $S$. zeamais, $R$. dominica, and $O$. surinamensis was higher in the evaluations at 24 hours, based on $\mathrm{LD}_{50}$ and $\mathrm{LD}_{90}$ estimations, than at six and 12 hours of exposure. The increasing order of susceptibility to coumarin was $R$. dominica, S. zeamais and O. surinamensis.

An insect immobilization effect due to coumarin exposure in this bioassay seemed to take place. A slowly developing paralysis is a major feature of insect poisoning by coumarin (Nicholson \& Zhang, 1995). In this context, there are close parallels with the botanical insecticide rotenone, antimycin A, and hydramethylnon, all of which block the electron transport in the respiratory process (Nicholson \& Zhang, 1995). As surangin $B$ is a potent inhibitor of mitochondrial electron transport in vitro, and as it produces a significant reduction

Table 2. Mortality (\%) of adult insects of Oryzaephilus surinamensis, Sitophilus zeamais and Rhyzopertha dominica, at 6, 12, 24 and 48 hours after topical application of 5,6,7,8,3',4',5' '-heptamethoxyflavone (H), coumarin (C) and 5,6,7,8,3'-pentamethoxy4',5'-methylenedioxyflavone (P) extracted from leaves of Ageratum conyzoides ${ }^{(1)}$.

\begin{tabular}{|c|c|c|c|c|}
\hline Insect species & Control & $\mathrm{H}$ & $\mathrm{C}$ & $P$ \\
\hline & \multicolumn{4}{|c|}{ Six hours after topical application } \\
\hline O. surinamensis & $0.00 \pm 0.00 \mathrm{bA}$ & $2.10 \pm 0.00 \mathrm{bA}$ & $35.00 \pm 4.36 \mathrm{aA}$ & $0.00 \pm 0.00 \mathrm{bA}$ \\
\hline S. zeamais & $0.00 \pm 0.00 \mathrm{bA}$ & $0.00 \pm 0.00 \mathrm{bA}$ & $0.00 \pm 0.00 \mathrm{aC}$ & $0.00 \pm 0.00 \mathrm{bA}$ \\
\hline \multirow[t]{2}{*}{ R. dominica } & $0.00 \pm 0.00 \mathrm{bA}$ & $3.33 \pm 3.33 \mathrm{bA}$ & $16.67 \pm 6.67 \mathrm{aB}$ & $0.00 \pm 0.00 \mathrm{bA}$ \\
\hline & \multicolumn{4}{|c|}{12 hours after topical application } \\
\hline O. surinamensis & $0.00 \pm 0.00 \mathrm{bA}$ & $3.33 \pm 1.16 \mathrm{bA}$ & $37.00 \pm 4.36 \mathrm{aA}$ & $0.00 \pm 0.00 \mathrm{bA}$ \\
\hline S. zeamais & $0.00 \pm 0.00 \mathrm{bA}$ & $0.00 \pm 0.00 \mathrm{aA}$ & $7.04 \pm 93.53 \mathrm{aC}$ & $0.00 \pm 0.00 \mathrm{bA}$ \\
\hline \multirow[t]{2}{*}{ R. dominica } & $0.00 \pm 0.00 \mathrm{bA}$ & $4.33 \pm 3.33 \mathrm{bA}$ & $23.33 \pm 8.82 \mathrm{aB}$ & $0.00 \pm 0.00 \mathrm{bA}$ \\
\hline & \multicolumn{4}{|c|}{24 hours after topical application } \\
\hline O. surinamensis & $0.00 \pm 0.00 \mathrm{bA}$ & $3.43 \pm 2.26 \mathrm{bA}$ & $78.53 \pm 3.13 \mathrm{aA}$ & $0.00 \pm 0.00 \mathrm{bA}$ \\
\hline S. zeamais & $0.00 \pm 0.00 \mathrm{bA}$ & $0.00 \pm 0.00 \mathrm{aA}$ & $10.37 \pm 0.37 \mathrm{aC}$ & $0.00 \pm 0.00 \mathrm{bA}$ \\
\hline \multirow[t]{2}{*}{ R. dominica } & $0.00 \pm 0.00 \mathrm{bA}$ & $5.67 \pm 3.33 \mathrm{bA}$ & $43.33 \pm 14.53 \mathrm{aB}$ & $0.00 \pm 0.00 \mathrm{bA}$ \\
\hline & \multicolumn{4}{|c|}{48 hours after topical application } \\
\hline O. surinamensis & $0.00 \pm 0.00 \mathrm{bA}$ & $4.43 \pm 2.26 \mathrm{bA}$ & $96.00 \pm 2.37 \mathrm{aA}$ & $0.00 \pm 0.00 \mathrm{bA}$ \\
\hline S. zeamais & $0.00 \pm 0.00 \mathrm{bA}$ & $0.00 \pm 0.00 \mathrm{bA}$ & $13.09 \pm 2.56 \mathrm{aC}$ & $0.00 \pm 0.00 \mathrm{bA}$ \\
\hline R. dominica & $0.00 \pm 0.00 \mathrm{cA}$ & $13.33 \pm 6.67 \mathrm{bA}$ & $68.89 \pm 11.6 \mathrm{aB}$ & $0.00 \pm 0.00 \mathrm{cA}$ \\
\hline
\end{tabular}

${ }^{(1)}$ Means followed by the equal small case letters in the line or equal capital letters in the column are not significantly different by the Scott-Knott test, at $5 \%$ probability. 
Table 3. Toxicity of coumarin, extracted from leaves of Ageratum conyzoides, against adult insects of Oryzaephilus surinamensis, Sitophilus zeamais and Rhyzopertha dominica ${ }^{(1)}$.

\begin{tabular}{|c|c|c|c|c|c|}
\hline Insect species & Slope \pm SE & $\mathrm{LD}_{50}\left(\mathrm{mg} \mathrm{g}^{-1}\right)^{(2)}(95 \% \mathrm{CL})$ & $\mathrm{LD}_{90}\left(\mathrm{mg} \mathrm{g}^{-1}\right)(95 \% \mathrm{CL})$ & $\chi^{2}$ & Probability \\
\hline & \multicolumn{5}{|c|}{ Six hours after topical application } \\
\hline O. surinamensis & $4.15 \pm 0.07$ & $3.86(3.51-4.25)$ & $14.06(11.55-18.21)$ & 0.29 & 0.87 \\
\hline R. dominica & $2.76 \pm 0.25$ & $39.71(35.90-44.99)$ & $115.18(88.88-173.90)$ & 6.27 & 0.09 \\
\hline \multicolumn{6}{|c|}{12 hours after topical application } \\
\hline O. surinamensis & $3.76 \pm 0.09$ & $3.71(3.36-4.12)$ & $8.11(6.94-9.88)$ & 1.00 & 0.81 \\
\hline R. dominica & $2.87 \pm 0.18$ & $20.82(18.70-23.08)$ & $58.04(49.40-71.65)$ & 3.17 & 0.37 \\
\hline \multicolumn{6}{|c|}{24 hours after topical application } \\
\hline O. surinamensis & $4.02 \pm 0.25$ & $2.72(2.47-2.98)$ & $5.65(5.07-6.43)$ & 6.50 & 0.09 \\
\hline R. dominica & $2.37 \pm 0.26$ & $11.82(10.07-13.59)$ & $42.94(34.67-50.30)$ & 6.93 & 0.07 \\
\hline S. zeamais & $3.16 \pm 0.25$ & $6.00(5.42-6.76)$ & $15.23(12.49-19.93)$ & 3.74 & 0.29 \\
\hline
\end{tabular}

${ }^{(1)} \mathrm{SE}$ : standard error; CL: confidence limit.

in ATP in vivo, the bioenergetic muscle disruption is a prominent mechanism underlying the insecticidal action of this coumarin. The surangin B has the potential to release the neurotransmitter centrally in insects (Nicholson \& Zhang, 1995). The enhanced release of the neurotransmitter from insect synaptosomes, and the substantial increase in miniature excitatory postsynaptic currents (EPSC) frequency, which precedes a loss of neural activity, are the result of intraterminal mitochondria failing to buffer $\mathrm{Ca}^{2+}$ effectively, and maintain ATP (Zheng et al., 1998).

Zheng et al. (1998) showed that surangin B has the potential to cause substantial functional disturbances in both muscle mitochondria and nervous system mitochondria in vitro. The state 3 of respiration was blocked by surangin $\mathrm{B}$, in cricket Acheta domesticus (Linnaeus) (Orthoptera: Gryllidae) and blowfly Phaenicia sericata (Meigen) (Diptera: Calliphoridae) flight muscle mitochondria. The coumarin surangin B acts as an inhibitor of mitochondrial electron transport, probably, targeting the cytochrome c oxidoreductase (complex III) and cytochrome b. This mechanism is similar to the beta-methoxyacrylates, which bind to the cytochrome $\mathrm{bc}_{1}$ complex, at a site distinct from antimycin, the classical blocker of electron flow between cytochrome b and c (Zheng et al., 1998). In addition, coumarin and mainly furanocoumarins can also alter the detoxication capability of an organism, by reversibly or irreversibly inhibiting cytochrome P450 detoxication enzymes (Letteron et al., 1986; Neal \& Wu, 1994). These studies are suggestive of the insecticide activity, mode of action and potential of use of coumarin from A. conyzoides, which will be the object of future attention.

\section{Conclusions}

1. Only hexane extract of Ageratum conyzoides shows toxicity to Sitophilus zeamais, Rhyzopertha dominica and Oryzaephilus surinamensis.

2. Coumarin extracted from A. conyzoides shows high toxicity to $S$. zeamais, $R$. dominica and O. surinamensis.

3. O. surinamensis is the most susceptible species to coumarin, followed by $S$. zeamais, and $R$. dominica.

\section{Acknowledgements}

To Coordenação de Aperfeiçoamento de Pessoal de Nível Superior (Capes), Conselho Nacional de Desenvolvimento Científico e Tecnológico (CNPq) and Fundação de Amparo à Pesquisa do Estado de Minas Gerais (Fapemig), for scholarships, fellowship, and grants received, respectively.

\section{References}

ABBOTT, W.S.A method of computing the effectiveness of insecticide. Journal of Economic Entomology, v.18, p.265-267, 1925.

BELMAIN, S.R.; NEAL, G.E.; RAY, D.E.; GOLOP, P. Insecticidal and vertebrate toxicity associated with ethnobotanicals used as postharvest protectants in Ghana. Food and Chemical Toxicology, v.39, p.287-291, 2001.

BOUDA, H.; TAPONDJOU, L.A.; FONTEM, D.A.; GUMEDZOE, M.Y.D. Effect of essential oils from leaves of Ageratum conyzoides, Lantana camara and Chromolaena odorata on the mortality of Sitophilus zeamais (Coleoptera: Curculionidae). Journal of Stored Products Research, v.37, p.103-109, 2001.

BRUNHEROTTO, R.; VENDRAMIM, J.D. Bioatividade de extratos aquosos de Melia azedarach L. sobre o desenvolvimento de Tuta absoluta (Meyrick) (Lepidoptera: Gelechiidae) em tomateiro. Neotropical Entomology, v.30, p.455-459, 2001. 
DEV, S.; KOUL, O. Insecticides of natural origin. New York: Harwood Academic, 1997. 352p.

FIELDS, P.G.; XIE, Y.S.; HOU, X. Repellent effect of pea (Pisum sativum) fractions against stored-product insects. Journal of Stored Products Research, v.37, p.359-370, 2001.

GUERRA, M.S. Receituário caseiro: alternativas para o controle de pragas e doenças de plantas cultivadas e seus produtos. Brasília: Embrater, 1985. 166p.

HIDALGO, E.; MOORE, D.; PATOUREL, L.E. The effect of different formulations of Beauveria bassiana on Sitophilus zeamais in stored maize. Journal of Stored Products Research, v.34, p.171-179, 1998.

KIM, S.; ROH, J.Y.; KIM, D.H.; LEE, H.S.; AHN, Y.J. Insecticidal activities of aromatic plant extracts and essential oils against Sitophilus oryzae and Callosobruchus chinensis. Journal of Stored Products Research, v.39, p.293-303, 2003.

LARSSON, S.; LUNDGREN, L.; OHMART, C.P.; GREF, R. Weak responses of pine sawfly larvae to high needle flavonoid concentrations in scots pine. Journal of Chemical Ecology, v.18, p.271-282, 1992.

LETTERON, P.; DESCATOIR, P.; LARREY, D.; TINEL, M.; GENEVE, J.; PESSAYRE, D. Inactivation and induction of cytochrome P450 by various psoralen derivative in rats. Journal of Pharmacology and Experimental Therapeutics, v.238, p.685-692, 1986.

LE-VAN, N.; PHAN, T.V.C. Two new flavones from Eupatorium coelestinum. Phytochemistry, v.18, p.1859-1861, 1979.

NAKAKITA, H. Stored rice and stored product insects. In: NAKAKITA, H. (Ed.). Rice inspection technology. Tokyo: A.C.E. Corporation, 1998. p.49-65.

NEAL, J.J.; WU, D. Inhibition of insect cytochromes P450 by furanocoumarins. Pesticide B0iochemistry and Physiology, v.50, p.43-50, 1994.

NICHOLSON, R.A.; ZHANG, A. Surangin B: Insecticidal properties and mechanism underlying its transmitter releasing action in nerve terminal fractions isolated from mammalian brain. Pesticide Biochemistry and Physiology, v.53, p.152-163, 1995.

ONYILAGHA, J.C; LAZORKO, J.; GRUBER, M.Y.; SOROKA, J.J.; ERLANDSON, M.A. Effect of flavonoids on feeding preference and development of the crucifer pest. Journal of Chemical Ecology, v.30, p.109-124, 2004.
QUIGNARD, E.L.J.; POHLIT, A.M.; NUMOMURA, S.M.; PINTO, A.C.S.; SANTOS, E.V.M.; MORAIS, S.K.R.; ALECRIM, A.M.; PEDROSO, A.C.S.; CYRINO, B.R.B.; MELO, C.S.; FINNEY, E.J.; GOMES, E.O.; SOUZA, K.S.; OLIVEIRA, L.C.P.; DON, L.C.; SILVA, L.F.R.; QUEIROZ, M.M.A.; HENRIQUE, M.C.; SANTOS, M.; PINTO, P.S.; SILVA, S.G. Screening of plants found in Amazonas State for lethality towards brine shrimp. Acta Amazonica, v.33, p.93104. 2003.

QUIJANO, L.; CALDERON, J.S.; GOMEZ, F.; SORIA, I.E.; RIOS, T. Highly oxygenated flavonoids from Ageratum corymbosum. Phytochemistry, v.19, p.2439-2442. 1980.

SAXENA, R.C.; DIXIT, O.P.; SUKUMARAN, P. Laboratory assessment of indigenous plant extracts for antijuvenile hormone activity in Culex quinquefasciatum. Indian Journal Medicine Research, v.95, p.204-206, 1992.

SHAALAN, E.A.S.; CANYON, D.; YOUNES, M.W.F.; ABDELWAHAB, H.; MANSOUR, A.H. A review of botanical phytochemicals with mosquitocidal potential. Environment International, v.31, p.1149-1166. 2005.

SHAAYA, E.; KOSTJUKOVSKI, M.; EILBERG, J.; SUKPRAKARN, C. Plant oils as fumigants and contact insecticides for the control of stored-product insects. Journal of Stored Products Research, v.33, p.7-15, 1997.

TALLARIDA, J.R. Drug synergism and dose-effect data analysis. Boca Raton: CRC. 2000. 247p.

TAPONDJOU, L.A.; ADLER, C.; BOUDA, H.; FONTEM, D.A. Efficacy of powder and essential oil from Chenopodium ambrosioides leaves as post-harvest grain protectants against six-stored product beetles. Journal of Stored Products Research, v.38, p.395-402, 2002.

ZHENG, J.; LEONG, D.; LEES, G.; NICHOLSON, A. Studies on the interaction of surangin $\mathrm{B}$ with insect mitochondria, insect synaptosomes, and rat cortical neurons in primary culture. Pesticide Biochemistry and Physiology, v.61, p.1-13, 1998.

ZITO, S.W.; ZIERG, R.G.; STABA, E.J. Distribution of pyrethrins in oil glands and leaf tissue of Chrysanthemum cinerariaefolium. Planta Medica, v.47, p.205-207, 1983. 